Jap. J. Leprosy 48, 2 (1979)

\title{
Rhinoplasty on Severe Damaged Noses in Leprosy
}

\author{
MASAMICHI KOSEKI \\ (Nippon Medical School, Dept. of Dermatology, \\ Dirctor: Prof. Seiichi HARADA)
}

\begin{abstract}
Some kinds of flaps which have both strong and weak points are employed for rhinoplasty in leprosy. The acromiopectoral tubed pedicle flap that one end is at the acromion and the other at the sternal center is the best with series of advantages through the experiences. The donor site where is closed by sutures without skin graft leaves good scar hidden by clothing not such as the operation scar in the case of forehead one's. And also, this flap requirs no standing for bothers with keeping arm's fixed position by the force as the jumped flap's and provides sufficient flap for total or subtotal rhinoplasty. But a few reconstructed nose has telangiectasia on itself.

The most important thing in rhinoplasty is how to keep the reconstructed nose without nostril stenosis in fine too long period, which depends upon prosthesis mostly.

The prosthesis made from the auto or preserved costal cartilage in L-shape is fixed completely in planted tissues with adhesive not the capsule holding as the artificial one's.

Additionally, to overcome the nostril stenosis, the striped composit graft from the herix is inserted into both alae.

The dish face correction is never neglected in leprosy, without this procedure, how the reconstructed nose is fine, it is strange in the face. So, this correction should be done by the nasal dorso-alar groove double pedicle flap moving to the atrophied upper lip region.
\end{abstract}

\section{重度ならい性外鼻変形に対する造鼻術について}

\author{
小閶正倫 \\ 日本医科大学㓟膚科教室（指導：原田誠一教授）
}

（受付：1978年12月15日）

\footnotetext{
緒言

らい性病変に上る顔面の変形に対して，形成手術の試 みはかなり古くから行わ机ていた年が，外鼻のそ机化っ いては，プロミンの効果が明らかなにった 1950 年前後 に，軽度ないし中等度鞍鼻の矯正を目的に隆鼻術が普及 しはじめ3,4)，っいで急速に扁鼻や斜鼻の整鼻術から,重
}

度な鞍鼻(沈下鼻または萎縮鼻)や欠損鼻の造鼻術にまで およんだ2。外鼻形成手術のこのめざましい発展は,化学 潦法の進歩もあるが，同時に形成資材，例えば，アクリル

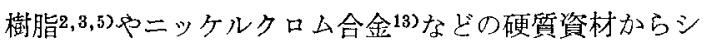
リコン系高分子材料(ジメチルポリシロキサン, DMPS) の上らな軟質資材 ${ }^{12}$ ，さらには自家肋軟骨や保存肋軟 骨9などの利用が容易になったことにもよる。 
ただ近年にいたり，プロミンその他の化学潦法剂がも たらした治らい效果は，外鼻变形を激減させた一方，化 学療法の恩恵に浴さなかった陳旧な症例の老龄化も著し くそその結果造鼻術の適応はかなりせばまってきた。た またま著者法，多磨全生園汇招いて造鼻術の数例を経験 し，貴重な症例として手術経過を追跡してみたが，そこ でさぐった問題点をつぎに報告したい。なお造鼻術に は，全ないし亜全造鼻術と部分造鼻術との両者がある が，本文にいう造鼻術とは全造鼻術についてである。

\section{造番術の症例と手術の経過}

著者の試みた造鼻術の症例は男子 2 例，女子 2 例の計 4 例であるが，こ机らの症例の概要を表 I 及び【に括め た。

\section{[症例 1]}

発病は昭和 9 年ころにさかのぼり，同29年ころかららい 腫性浸潤が顔面全体に掠よんだ。その後 $2 ， 3$ 年を経て 鼻橋の短縮後退と外鼻全体の萎縮陌凹（萎縮を伴ら沈下 鼻）を招き，昭和 35 年にアクリル樹指のプロテーゼによ る隆鼻術を受けたが，10年後に感染してプロテーゼは抜 去された（以上は沖繩愛楽園の記録による）。

昭和 52 年 2 月，再度，外鼻変形の矮正手術を希望して
多店全生園形成外科を訪れた。当時の所見は，顔面各所

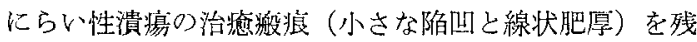
し，眉・睉毛のいずれも脱落，それに軽度な鬼眼（閉眼 時の服睑裂開大注 $1 \sim 2 \mathrm{~mm}$ ) 認めた。顔面中央の陌 叫（いわ功 dish face）はやや著明で，骨性外鼻江ほ とんど平坦化して，軟骨性外鼻も鼻翼・鼻橋をふくめて 萎縮し，鼻翼鼻背移行部の宿入（扁鼻翼）は外鼻孔の狭 窄を招き，鼻性呼吸困難を訴えた。要するにこの外鼻の 変形注，萎縮鼻，重度鞍鼻及び扁鼻の組合せであり，単 なる隆鼻術による镉正は困難と判断して, 造鼻術の計画 をたてた。

造鼻のための皮弁は，前額部が比較時狭险なこともあ ったが，顔面に新たな手術橪痕がつくられるのをためら い，前胸壁斜走管状皮弁をまず考えた。手術経過の概要 は表川に示したが，管状皮弁の移動，造鼻，自家肋軟骨 を用いたプロテーゼの埋入，耳介の皮膚・軟骨遊離複合 弁皮移植による外鼻孔形成，除脂肪などの補整手術は一 応型の通り行われ，これらの各段階に扝いて，結果に重 大な支障をもたらすよらな失敗はなかった。しかし外鼻 孔の形成は，耳介の皮虔・軟骨遊離複合皮并移植を試み たものの，主に鼻翼に対応する鼻前庭に限局して行った ため，十分な孔径が得られなかった。また造鼻の，こと

表 I 症例内訳

\begin{tabular}{|c|c|c|c|c|c|c|}
\hline No. & 症例 & 性别 & 年齢 & 発病 & 鼻変形のはじまった年月日 & 過前の外鼻形成手術とその結果 \\
\hline 1 & M.N. & 女 & 54 & 諮 9 & 沼和 30 年 & $\begin{array}{l}\text { アクリル樹脂プロテーゼによる隆鼻術, プロテー } \\
\text { ゼ感染による技去失敗 }\end{array}$ \\
\hline 2 & T.S. & 女 & 53 & 炤 6 & 嚁和15，16年 & $\begin{array}{l}\text { DMPS による隆鼻術，自家腸骨による隆舅術， } \\
\text { ともにプロテーせ染にり敗 }\end{array}$ \\
\hline 3 & Y.K. & 罗 & 52 & 昭31 & 昭36年 6 月すでに鞍鼻 & なと \\
\hline 4 & Y.S. & 男 & 66 & 昭 21 & 炤 21 年 3 月すでに外鼻変形 & $\begin{array}{l}\text { 前胸壁斜走管状皮弁による全造鼻術(プロテーゼ } \\
\text { (アクリル樹脂)感染により失敗 }\end{array}$ \\
\hline
\end{tabular}

病型はいすれる「らい腫型」，手術当時に鎮静期にあった。

表 II 手術の経過

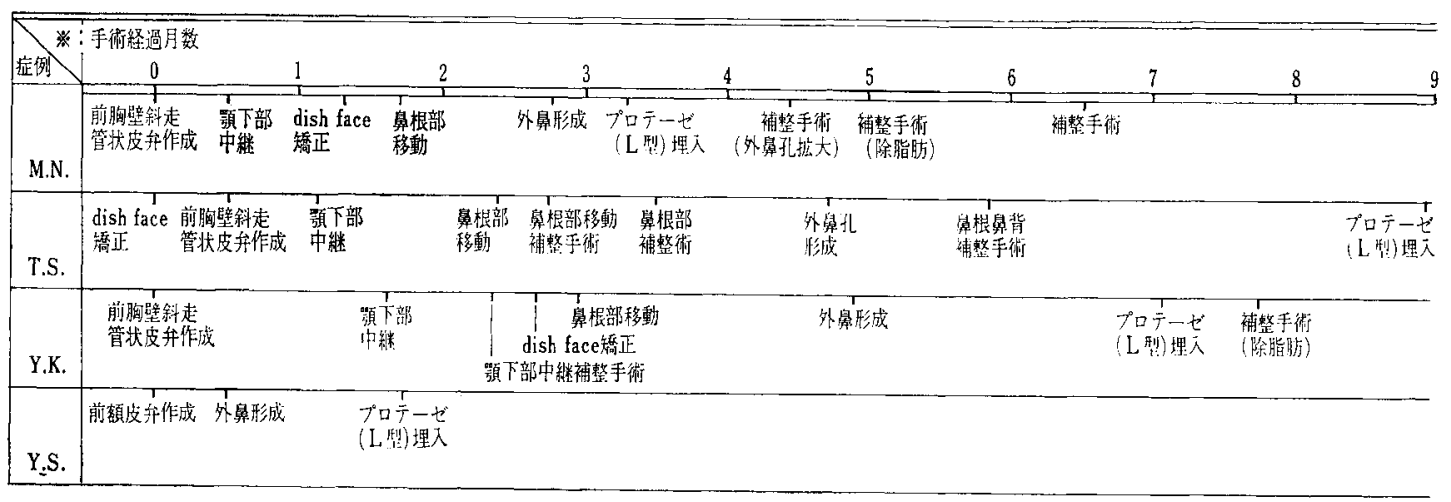


に鼻背から鼻尖にかけて，非感染性の色素沈着（暗赤紫 色汇近い）残した。この色素沈着は，プロテーゼの埋 入以前に認めなかったから，プロテーゼを鼻背皮下に残 く埋入しすぎたか，あるい愉脂肪が過量にすぎたのか いずれかと思われるが，約 1 年半を経過してごくわずか ながら退色傾向を示している。

\section{〔症例 2〕}

発病は昭和 6 年ころ, 外鼻の変形は昭和 15 年から16年 にかけて，らい病状の増悪に並行しては㤌をった。昭和 40年に, シリコン系高分子材料 (DMPS) のプロテーゼ を用いた隆鼻術が行われたが，感染したため抜去された という(宮古南静園の記録による)。

昭和52年 3 月，外鼻変形の稪正希望して多磨全生園 形成外科を訪れた。当時の所見によると，眉毛はややう すく残存し，顔面神経麻愺はなかった。しかし顔面中央 部はかなり著明に陌凹（dish face）し，骨性及び軟骨性 外鼻法いずれも萎縮して，鼻背のほぼ正中には手術旅痕 （前述のプロテーゼを拔去した際のものといら）が認め られ，外鼻孔は前面をむいて左右ほぼ円形，孔径約 3.5 $\mathrm{mm}$ ，鼻橋注退縮し鼻中隔は全欠損に近かった。以上の

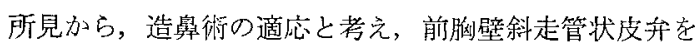
用いる方法を計画した。

手術期間の短縮をはかる目的（後述するように，尖際 注管状皮弁の移動にとどまり，この目的法達せられなか った）で, dish face の矯正から注じめた。ついで左前 胸壁斜走管状皮弁の造設にかかり，3 週後に胸骨端部を 額下部に移動し，さらに 5 週後，鎖骨端部を鼻根部に移 動したが，移動部の毉張が強く循環障害を招いた。そこ で 3 週後に壊死部分を切除し, 過緊張を警戒して左鼻唇 溝部に再移植した。 5 週後には颚下部中継端を切離し， 管状皮弁を展開して両鼻翼と鼻矯をかたちづく，外鼻 の下半分を再建した。こらして5 週後, ようやく鼻莀溝 中継端を切離し，鼻根部に移動して造鼻を終った。以後 の自家肋軟骨プロテーゼ，耳介皮膚軟骨遊離複合皮弁に よる外鼻孔形成などは型の通り進めた。

本症例柱，かなり肥满した婦人で，幅 $8 \mathrm{~cm}$ の皮弁在 丸めたとき，皮下脂肪織がやや過量であったために，全 体に過緊張ぎみで柔軟性が方しく，顎下部から鼻根部 の架橋に無理があって，鼻根部移動端に循環障害を招、 たものである。

[症例 3]

昭和31年ころ発病，当初より顔面にらい腫性浸潤があ り，昭和36年 6 月，多磨全生園に入園した。当時すでに
中等度の鞍鼻を認め，昭和 40 年前後にはじまった病状の 堌悪とともに，沈下鼻の㥞相を呈してきた。その後数年 のらちに病状は一応鎮静し，外鼻变形の矯正を希望して 形成外科を訪れた。

受診時の顔面は，B 663による色素沈着がかなり著明 であり，ほとんど全域にらい性潰瘍による線状搬痕と洀 痕性萎縮を認めた。眉毛及び㫸毛は完全に脱落し，顔面 神経麻瘦はないが, dish face を伴う定型的な沈下鼻を 呈して，鼻根部江平坦，外鼻孔は $3 \mathrm{~mm}$ 径ほどであり， また鼻中隔の完全久損による鼻性呼吸困難を訴えた。

そこで造鼻術の適応と考え，まず左胸壁斜走管状皮弁 を作成し， 7 週後に胸骨端を左顎下部に移動，さらに 6 週後, 鎖骨端部鼻根部に移動したが，この間にdish face の矯正を鼻唇溝皮弁法により行った。 5 週後には 頻下部中継端を切離して雨鼻翼と鼻橋をつくり, 約20日 後に自家肋軟骨プロテーゼを埋入してかたちをととのえ た。しかし本症例は，この7カ月後に鼻尖部の皮下に膿 瘍をつくり，埋入プロテーゼの一部が露見するにいたっ た。炎症は抗生物質の投与によって一応消退したが，プ ロテーゼの鼻尖部の一部が分離排泄された。炎症は鼻全 体，ことに鼻橋と鼻翼の部分に強く，消退とともにや や瘢痕性に萎縮した。患者は余手術（プロテーゼの再埋 入）希望しているが，プロテーゼの上うな姑息的な矯 正では，萎縮した鼻橋を延長して鼻尖を挙上するのは困 難之考え, 再度の造鼻術（前額皮弁法）を計画したが, それについての患者の同意が得られす，い未も放置され たままになっている。本症例から,プロテーゼによって は，たとえ感染しても保存的に処置してよいことを知っ たが，感染初期の処置をおこたったため（招こたったよ りは，感染初期をみすごしたといらのが当っている。こ れは造鼻自体に知賞が再生されていなかった時期に感染 し，自営症状が欠如していた事尖も大きい）に，政痕萎 縮を招き結局は造鼻の効果を失った。

\section{[症例 4]}

昭和21年，発病と同時に多磨全生園化入所したという が，実際にはそのころすでに顔面のらい腫性浸潤は著し く, 外鼻にも変形 (鞍鼻) が認められた。しかし治潦ら しい治療も受けず自ら退所し，眧和 35 年に再入所してき た。社会にあって顔面の変形は, 病状の進展に伴い一そ う增悪し, 眉・睷毛の脱落, 顔面全域の般痕形成(こと に雨下眼瞼の滦痕性外反が目立った），沈下鼻などいず れも著明になっていた。昭和40年12月から 6 力月あまり 要して左前胸壁斜走管状皮弁法に上る造鼻術が行われ 
たが，プロテーゼ（アクリル樹脂製）の感染事故を招 き，造鼻の効果は鳥有に㷌してしまった。

昭和52年 8 月再手術を希望したので，前額皮弁による 造鼻術を計画した。この患者の場合, 顔面のらい腫性病 変による症痕形成はかなりはげしかったが，前額部に限 れば，癜痕は皮内にとどまって皮下と漓着せず，また側 頭動脈も触診上は異常它認めなかった。前額皮弁のため の皮切注，ます右側外眼角部の高さにおいて，右眉端外 側から右眉上部を経て左届端部にいたり，そこから半円 を描くよらに前額の髮の生え際に移って，さらに生え際 沿いに右側頭前部に達する。こうして骨膜から剝離した 前額皮弁を平面的な外鼻形（いわゆる外鼻錐体をそいだ かたら）になぞらえた創面（移植床）に回転移植したが， 半円状の先進部をもって畜翼と舅橋をかたちつくった。 10日後に鼻根部の形成に必要な長さの上ころで皮弁を切 離し，残余皮弁を前額の旧位置に戻すとともに鼻根部を 形成した。前額の造鼻のための皮膚欠損部は，左大腿よ り採取した遊離中間層皮弁をもって被った。約 2 力月後 に同種保存肋軟省プロテーゼを埋入し, さらに1 力月後 には，耳介の遊雕皮䖉・軟骨複合皮弁を用いて両側鼻孔 を形成したが，6力月を経た現在，造鼻自体の審美的効 果注ぼ渵足できる。しかし前額遊傩植皮部は, 生着が 一部不良であった部分の洀痕がかなり目立つ。

\section{小 括}

以上の 4 症例について，全体を補足しながらつぎに括 めてみる。

(1) Premedication

らいに和いて造舅術を希望する患者の年蹂は，40歳以 上65歳未満にほぼかきられるから，年龄的にはあまり問 題にしなくてもよいが，らいの病状については注意を要 する。少なくとも，皮膚の叙抹標本加らはらい菌を証明 せず，病勢は arrest の状態か，もしくは鎮静期を 2 ， 3 年以上経過していなくてはならない。手術は皮弁の造 設と胁軟骨の採取にかぎり全身麻瘦下に行らのがのぞま しいが，之の他の過程は寻所麻酔でも足りる。しかし数 次にわたる侵襲とそれに伴ら出血量注，決して小さくな いから，手術間隔がせばまるほど，心・肝・腎機能の異 常と貧血の有無忞常に注意し，また対象のほと儿どが重 度ならい腫らいである関係上，副腎機能の不全やらいの 再然を考慮におく必要がある。

（2）管状皮弁による造鼻術

管状皮弁については，胸壁皮弁を顎下部に中継する場
合と腹壁皮弁前腕に中継する場合(いわゆる jumped flap）とが一般的であるが，著者は前者に限って試み た。

\section{（2-1）胸壁斜走管状皮茅の造設}

胸壁にらい腫性瘵痕は少ないから，手術野に㧍けるそ

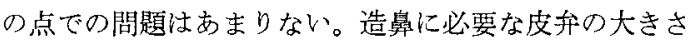
は，幅 $8 \mathrm{~cm}$ ，長さ $18 \mathrm{~cm}$ ほどあればよいが，これを鎖骨 外側端部から胸骨中央部へ斜走寸るようにつくる。この 皮弁の厚さ，つまり皮下脂肪織量は，鎖骨側 $1 / 3$ がほぼ 全量を(筋膜から剝離)，胸骨側 $2 / 3$ はなるべく附着さ せる程度とし，これを管状に丸めてみて皮下脂肪織が過 量と思われれば，横断面が逆台形になるように，なる心 く両翼から皮下脂肪織を切除する。母床は一次的に閉鎖

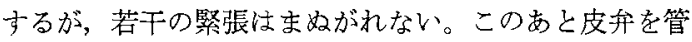
状に丸めて縫合寸るが，母床に横たえたとき，とくに荅 刍な部分が認められず，かつ円筒状に丸みを帯びる程度 であればよく、もし循環障害があると思われれば,ちゆら ちよせず縫合を解き，上記の要領で皮下脂肪織の適量を 切除子る。以上は全身麻酔下に行われるが，局所麻酔で も可能である。術後10日目までに全抜系を行い，管状皮 弁の胸骨側端部をクレンメで王迫阻血し，当初10分から はじめて，1週間ほどのちに 1 時間をで延長できれ恬， 管状皮弁の血行は十分上考えてょく，これを確認してつ ぎの中継に移る。

\section{(2-2）管状皮弁の顎下部中継}

前胸壁斜走管状皮弁は，乙の鎖骨側端部が造鼻に利用 されるから，胸骨側端部を顎下部に中継することにな る。中継の方法は，成四汸らのそれに準して，切断され た胸骨側端部の皮膚を，ほぼ中間層の厚さで率輪状（幅 約 $7 \mathrm{~mm}$ ) に剝離切除し，この部分を顎下部にっくった 皮下脂肪織に及ぶ切創 $(2.5 \mathrm{~cm}$ あれば是りる)をおしひ ろげて埋植するが，それによって管状皮弁の屈曲やねじ れは最小ですむ（Schema 2)。7ない 10 日後に抜絭 し，鎖骨側端部をクレンメで挾み，前回と同様の要領で 血行の胿盛をはかる。

(2-3) 管状皮弁の鼻部移動（鼻根及び鼻背雨翼の形 成) (Fig. 4)

中継後 2 週間以上おいて，血行が十分と思われれば， 局所麻酔下に管状皮弁の鎖骨側端部を切離し，これを鼻 根部に移動する。鼻根部の移植末日つくり方は, 両側の 悬翼基部上方から戴金点に頂点をおく放物線状の皮切を 加え，この皮切に囲まれた皮膚を剝離切除すればよい。 皮贲（管状皮弁の遊離端）はこの創面に合せてやや斜め 
に裁断し，また皮弁の（管状に縫合した）縫合洀痕は， その後面において黄金点を通る正中に位置させる。

術後の処置は, 前回の中継にお就る場合に準してて行 う。

(2-4) いわゆる dish face の矯正 (Fig. 3, Schema 3)

管状皮弁の 䫈下部中継ないしは 鼻根部移動に 並行し $\tau$, dish face を镉正する。著者は成田 $\left.{ }^{12}\right)$ とは逆に, 鼻 唇溝の鼻翼下方に茥をおき，鼻背の中央部で結ばれる双 脚鼻唇溝皮弃をつくり，これを退縮した上口唇部をひき さげるためにできた欠損創に移植した。これによって見 がけの煩部隆起と，実際の上口居退縮が同時に矯正され る。拔系は 7 １0日目にかけて行5。

(2-5) 鼻背と鼻橋の形成 (Fig. 5)

鼻部に移動した管状皮弁の血行が十分であれば，顎下 部中継端を適当に離断し, 残部の理植皮弁を切除して顎 下部の創を閉しる。ついで遊離部分の管状皮弁を顔面正 中に颃いて，上口唇赤唇をこえた余剩分を切断する。こ のあと管状皮弁の既植部分の下部を弁状に展開するが, その場合の皮弁の幅注，管状皮弁をつくった当初に比べ てかなり萎縮しているすのの, 必要な $6 \sim 7 \mathrm{~cm}$ の幅は 十分にある。展開した皮弁の先端を半円状にデザイン し，これ正中でおり合せて，端部の $2 \mathrm{~cm}$ ほどを鋁子 ではさみながら，直角に打りまげれば (Schema 4)，

鼻橋と鼻背のかたらがつくられる。そのまえに、、わ 西る外鼻錐体の下半分をそいだよらなかたちの移植床 (Schema 5) を，鼻部にあらかじめっくっておき，そこ に皮弁の鼻翼と鼻橋に相当する部分を移植すればよい (Schema 5)。なお鼻橋基部の 確実な生着をはかるため に, この部分だけ表皮を剝切し, 移植床の創内に埋めこ むように移植する。術後は内径 $7 \mathrm{~mm}$ のシリコン管を累 腔内に雨入して狭窄を防ぎ，抜系性 7 日目に行う。

(2-6) 除脂肪及びプロテーゼの埋入

以上で一応の造鼻を終るが，その3カ月あまりのち に, 鼻尖部に加えた切開創から，主として鼻背と鼻尖に かけての除脂肪を行い，自家肋軟骨かまた海存肋軟骨 でっくられたプロテーゼ（Fig．6）を埋入する。プロテ 一ゼのかたちは，I型を基本としているが，鼻背部分と 鼻橋部分がかならずしも一連にならなくともよく，舟型 の鼻背部分と, 細い短冊型の鼻橋分を, 鼻尖部において 単に重ねるだけのこともある。しかしプロテーゼの材料 に人工資材を用いるのであれば，L型プロテーゼの鼻尖 部分は一連のであったほうがよい。それは自家または保
存肋軟骨であれ标，組織内被包が線維性洏合によって強 固9なものに齐し，人工資材はらすい被膜をむって囲ま れるにすぎないかからである。

な㧍プロテーゼを埋入して，鼻背を美しくみせる（鼻 子じの通ること）ために，鼻背の雨翼にガーゼ塊を㧍い て圧迫固定する場合もあるが，それには壊死を伴ら危険 がないでもない。ゆえに，術後（とくに手術直後）のプ ロテーゼ効果にこだわらず，後日の補整手術に期待する ことにし，また外鼻孔の狭窄を防ぐために，シリコン鼻 管の送入はつづけて抢く。通常はこの段階の手術にかぎ り，感染防止のための抗生物質の与薬を，抜糸までの 1 週間にわたって行う。

\section{(2-7) 外鼻孔の形成}

プロテーゼを埋入して 2 カ月ほどのちに, プロテーゼ の効果が不十分と思われれば，鼻背両翼を再切開して， なるべくプロテーゼを露出しないように注意しながら除 脂肪を行い，同時に余剩な鼻背两翼皮薄を切除維縮す る。もしこの必要がなければ，外鼻孔に隣る鼻前庭に， 数 $\mathrm{mm}$ 幅の皮膚㧍よび皮下脂肪織を切除した創をつく りここに短册型の耳介の遊睢皮䖉・軟骨複合皮弁を移 植する(Schema 6)。この遊離植皮は，活と九ど確実に 成功するから，生着した耳介軟骨によって，外鼻孔の突 狭は一応防がれる。ただ生着が確かと思われたあとも， できればその後 3 カ月余りは, シリコン管を送入してお いたほらがよい。な拉上述の除脂肪と外鼻孔の形成のた めの耳介の遊離皮膚・軟骨複合皮弁移植は，原則亡して 同時に行わず，できれば月余の間隔を拄いたほうが事故 は少ない (Fig. 7)。

（3）前額皮弁法による造鼻術

前額皮弁を造鼻に用いる場合, 荎をどの部位におくか 問題になる。届間部，耳前部，側頭部などいるいるある が，著者はデザインが容易なことと，また回転角が小さ いための安全などを考えて，耳前部茎をおく皮弁を用 Wた。

\section{(3-1) 前額皮弁の造設}

造鼻のための前額皮弁は, 幅 $6 \sim 7 \mathrm{~cm}$, 長さ $15 \mathrm{~cm}$ ほ どで，ほとんど前額全域を利用することになる。この皮 弁を鼻部に回転したとき，半円状先端部は上口唇赤唇部 に無理なく達し，かたちづくられた两鼻翼，ことに皮弁 茎部の対側の鼻翼(つまり，皮弁の茎が右耳前部であ机 ば，対側は左鼻翼）が不均等に緊張するようであっては ならずまた鼻尖部にも緊張なく垂れるくらいの余裕が ほしい。な拉皮弁をつくる際に，骨膜を不注意に損傷し 
たりまたその一部を前頭骨から剝離することのないよ 5，皮切に先立ち，生理的食塩水を皮下に注射して浸潤 させるとよい。皮弁を採取したあとは，欠損部を中間層 植皮をもっておぎならが，著者梳血を確実にしたのち シリコンガーゼで括扔い，そのまま放置して次回の手術 までに肉芽の形成をまった。

(3-2) 皮弁先端の鼻部移動（鼻翼と鼻橋の形成） 前項でも触れたが，前額皮弁の半円状先端部をもって 鼻翼と鼻橋をつくり，いわゆる外舅錐体の平面的なかた ちの移植床にのせればよいが，鼻翼上舅橋のつくりかた は，管状皮弁の（2-5）に述べられているところと異 らない。ただ前額皮弁は，中継して再展開寸る管状皮弁 と異なり，鼻翼と鼻橋晋つくる先端部の血行はよいか ら，鼻尖のもりあがりをつくるための固定（鼻尖から鼻 背にかけての両翼に詨する玨迫国定）怯行う。もち万ん 管状皮弁の場合であっても，血行さえ良好であれば行っ てもさしつ汃えない。

(3-3) 移楦された前額皮荆の切離（崽根部の形成）

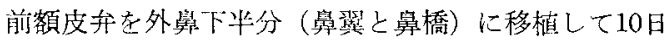
ないし 1 カ月後に，算根部の形成に必要な長さのところ で皮弁を切離する。残った前額皮弃注再びもとの採皮母 床に戻し，造鼻に利用しただけの久損部を，中問層桘皮 でおおう。移植皮弁はその正中をつまんで鼻背の隆まり をつくり，両翼を適当に切除して鼻根部を形成する。

(3-4) プロテーゼ理大：外鼻孔形成之の他

これらの手術については，すべて管状皮弁法による場 合と同梯である。

\section{考案}

造鼻術には，隣接皮弁を用いる方法と，遠隔皮弁者用 いるそれとがあるが，䫀用される皮贲としては，前者の

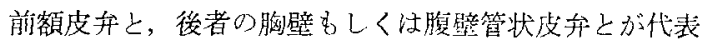
的である。

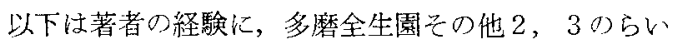
療養所に抬ける症例を観察して検討を加えた。

まず前額皮弁造鼻術は，造鼻自体の皮膚色が周辺（䒜 部や上口唇部）皮虔のそれによく一致しており，また手 術の所要経過がもっとも短かい点などでもすぐれてい る。しかし狭い前額部では十分な皮并が上りにくく，そ れに前額皮弁の採皮母床における植皮旅痕が目立つなど の問题がないでもない。ことに前額の植皮湶痕は，色素 沈着がしばしば著しいが，この退色は活とんど期待でき ずささらに造鼻自体の失敗が加わる上，同じ顔面の中で
醜形に醜形を重悋ることになる。

いずれにしても前額皮弁によれば，通常は 2 回の手術 をもって，1 カ月以内の短期間に造鼻は完了寸る。ただ

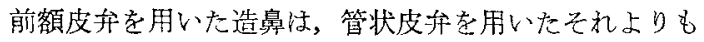
萎縮傾向がかなりつよいから，3力月のちのなる心゙く早 、時期に，プロテーゼの埋入を考えたほうがよい。

つぎに胸壁斜走管状皮弁による造鼻術は, 側腹壁もし くは下腹壁の管状皮弁を, 前腕橈側下端部に中継して鼻 部に移動するよりも苦痛訬ない点でなさる。

前胸部から採取する皮弁の幅は，造鼻にかかるまでの 萎縮を予测して通常は $7 \sim 8 \mathrm{~cm}$ 亦机ばよいが，これで

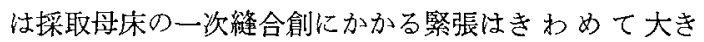
く，、きおい乳房は鎖骨側に強くひきよせられる。っっ ともこの手術痏痕が著しく肥厚することはむしろ少な く，乳房の偏位も経過とともにある程度目立たなくなる ことが多い。管状皮弁化よる造鼻汪，前額皮弁を用いた 場合とで手技自体に法あり異同流ないが，多量の皮下 脂肪織の処置，すなわちプロテーゼの埋入とともに行わ れる除脂肪は，舅尖部の小切開からするとかなりの困難 を伴う。ゆえにはじめ注，プロテーゼの埋入に十分な程 度の除脂肪にととめ, 後日, 鼻根部から鼻背両翼にかけ ての手術㾫痕を再切開し，プロテーゼが露出しないよう に注意しながら，再び除脂肪を行うほうがよい。

管状皮贲による造棉の大きな問題点の1つに，造鼻全 体のび漫性な毛細血管昖張があり，きわめて難治な上に 発症機転も明らかでなく，現状において特比有効と思わ れる手段はない(Fig. 8) 15)。

これまでに，隣接する前額皮弁と遠隔の管状波弁を用 いた造鼻術について，それぞれの問題点をのべたが，両 者に其通した造鼻そのものの問題むある。

まず造鼻のかたちを整え，それをそりまま維持してい くためには，適当なプロテーゼを用いなくてはならな い。このプロテーゼの形成資材にはいろいるあるが，特 にアクリル樹脂，DMPS，自家また沙存肋軟骨などは もっともしばしば利用しれる。通常のプロテーゼは，い わゆるL型プロテーゼであり，これに鼻翼軟骨に相当す る“張出し”をつけたものを成田は全外鼻型プロテーゼ と呼んだ(4)。こ机らのプロテーゼを用いた造鼻は，いわ ゆる外錐鼻体としてのプロフィールや正面像でみるかぎ り，美容的に注一応満足できる。しかし埋入さ竌たプロ テーゼの型を，造鼻のかたちとして効果的に表出するに は，プロテーゼをなるべく浅く皮下に埋入しなくてはな らない。そらなると，もっとも強く持ちあげられる鼻尖 
部では，皮膚が不断の緊張を強いられ，いきおい同部に 塄死や穿孔を起しやすくなり，ついには感染してプロテ 一ゼの抜去を余儀なくされる。つまりプロテーゼを埋入 して，造鼻のかたちにあまりこだわりすぎると，逆に造 鼻の永続性をそこなら結果になりかねない。

造鼻の永続性にかかわる事故流，もちろんプロテーゼ 以外沈むる（例光代外傷）が，らい患者における造鼻 についてみるかぎり，プロテーゼに基因するものがもっ とも多い。ただこのような事故は，アクリル樹脂やコバ ルトクロム（宋たはニッケルクロム）合金などの人工的 硬質資材に頻発し，DMPS などの人工的軟質資材には やや少なく，同種保存肋軟骨ではまれであり，自家肋軟 骨にいたってはまずないといってむよい。いずれにして も，プロテーゼを抜去したのちは，被膜腔が滀着して搬 痕化するが，それとともに，造鼻梳ほとんど原形をとど めないまでに荌縮する。ただこの萎縮の程度注, 皮下脂 肪織の量が少ない忹どはげしい。そこでプロテーゼを抜 去したあと，腔内の肉芽をできるだけ除去して，ただち に脂肪遊離移植を試みることもあるが，この生着はかな らずしも十分ではない。

搬痕萎縮におちいった造鼻は，移植によって失われた 皮膚の伸展性がさらに失われ，後日の再手術において， プロテーゼをどのように工夫しても，雷美的な改善はま ったく期待できなくなる。

皮弁のデザインに特別な困難はないが，少なくとも幅 $6 \mathrm{~cm}$ と, 鼻背及び鼻橋をつくる際に, 鼻尖部が緊張な くたれ下るくらいの师とりがほしい。皮弁のデザインに 関連して，大径と小径 2 ○管状皮弁を組合せ，小径の それをもって鼻翼の張り出しをつくる高橋ら 15$)$ 方法 は，管状皮并造鼻のために展開しないですむ点で有利 であっても，鼻背から鼻翼への移行が㗪痕によって強調 されすぎ，審美的にはかならずしも満足できない。ただ このような方法をふくめて，いくつかの手だてをもつこ とはのぞましい。

造鼻術の対象になる症例は，少なくともそれがらい性 病変によるものであるかぎり，大なり小なりのいわゆる dish face を伴う。dish face の意江顔面中央部の陌凹 をいうが，これは梨子状孔を中心とする上顎骨の陥凹で はなく，鼻骨の萎縮平坦化，鼻唇溝皮䖉の余剩（鼻唇溝 部が重くたれた感じとなり，鼻部の宿凹を一そうきわだ たせる)，そして鼻橋基部の退縮（上口唇が全体として 舅腔側に退縮（上顈歯前突に似ている）が主因である。 沙えに, 鼻根部の挙上, 鼻唇溝余剩皮膚の切除, 上口唇
退縮の矯正を行えば dish face は一応稪正されるが， 成田は鼻唇满皮弁を上口唇に回転移植して目的を達し $た^{12)}$

後述するが，外鼻孔の形成浩鼻のもっとも大きな難 点の1つであり，術前に括ける外鼻の変形の状態，つま り外鼻孔の搬痕狭韭がわずかで，上口唇の退縮が目立た なけ机ば，外鼻孔内面の前方を残して利用したほらがよ い。この場合には, dish face は，通常あまり明らかで ないが，鼻唇溝部のたるみだけは除いたほうが審美的に 満足である。

造鼻術後の外鼻孔の狭竅は，ほとんど必然的といって 上い。前述の高橋らの方法10) (大径及び小径の管状皮弁 の組合せ）も，この狭窘を意識してのものと思われる。 ほかに, 全外鼻型プロテーゼの埋入や，鼻腔をかこむ管 状の自家耳介軟骨移植も，実際問題として確かな効果の ほじは疑しい。著者は鬼冢らの方法16)をねて，外鼻孔 に隣る鼻前庭に, 耳介皮膚・軟骨の複合遊離皮弁の移植 を試みたが，それによってある程度满足できる結果を得 た。

造鼻のカラーマッチは，前額皮弁を用いた場合に，も っともすぐれていることはすでに述べた。しかし前胸壁 斜走管状皮弁を用いても，カラーマッチの点で前額皮弁 に特に劣るかけではない。むしろ管状皮弁を用いた場合 は，ややまれに特徴的にあらわれる不明の毛細血管昖張 症のほうが問題である。

\section{結＼cjkstart語}

著者は，らい患者について造鼻術の 4 症例を経験した が，さらに多磨全生園及びその他 $2 ， 3$ の療養所に枋け る同手術例をいくつかみて，若干の検討を加えてみた。 その結果, 著者の経験した 4 症例にお打る問題点が，他 の症例のそ机洪通していることを知り，のぞましい手 術の方法について，見解を括めた。

すなわち，少なくともらいにおける造鼻術には，のち

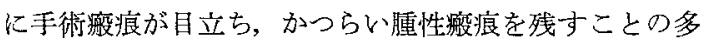
、前額の皮弁よりは，前胸壁斜走管状皮弁を用いるほう がのぞましく、これを顎下部に中継して造鼻を行う。こ の間にいわゆる dish face の矯正をはかり，をた造鼻 のプロフィールをつくるため, 自家胁㳄骨によるL型プ ロテーゼを用い，耳介皮膚・軟骨複合遊離皮贲を外鼻孔 に隣る鼻前庭に移植してその狭窄を防ぐ。

もし前胸壁斜走管状皮弁法が失敗した場合には，前額 皮弁法によるほかないが，この方法であれば手術期間が 
短かくてすむから，患者の説得には有利である。なお前 額皮弁は，外眼角側力に蒸をお゙てて前額全体を利用した ほうが，デザインの安易な点ですぐれていると考えた。

稿を終るにのぞみ，御愁篤な御指導と御校閱を賜った 日本医科大学皮膚科学教室・原田誠一教授に深甚な謝意 を表します。ならびに本研究について資料の提供をらけ た国立撚養所多磨全生園形成外科・成田稳医長に感謝い たし变す。なお本論文の要旨は The Second Congress of The Asian Pacific Section of The International Confederation for Plastic and Reconstructive Surgery (1977, Tokyo) のシンポジウム (Nasal Reconstruction）に扔いて発表した。）

\section{文献}

1）成田稳：形成外科領域に招ける Dimethylpolysiloranの忘用にあたって注意すべき基礎事項， 形成美容外科, $1: 299-307,1958$.

2）成田稳：前額有茥皮弁移植法に上る全造鼻術に ついて，および $2 ， 3$ の踛性鼻変形儿対する同 法の適応，形成美容外科， 1: 186-94，1958.

3）稲葉俊雄, 石河末松, 萩原鐘一：ら以患者の鼻 整形手術について，らい形成外科，4，5：15$23,1959$.

4）稲葉俊雄：らW性外鼻変形に対寸る隆鼻術の難 点, らい形成外科， $6: 1-2 ， 1960$.

5）成田稳：基本的な造鼻術について，外科治㙩， $3: 110-20,1960$.

6）成田稳，平賀久治：造鼻術に招ける胸壁斜走管
状皮弁の罝下部中継について，形成美容外科， $3: 171-4,1960$.

7) 成田稳，鈴木正和：前額皮弁法（いわゆるイン ド法）または胸腹壁管状皮弁移動法を用いた場 合の全造鼻術に敋ける失敗から，らい形成外科， $12: 1-6,1962$.

8）成田稔：5い性外鼻変形の形成外科, その基本 的な手術指針について，形成外科，5：164-9, 1962.

9）成田稳：条件の不良原同種保存肋軟骨を隆鼻材 料をして用いてみた経験，らい形成外科，21： 1-7, 1963.

10) 高橋良：顔面外科の形成外科（日本医師会編篹, 日本医師会医学講座, 昭和 39 年度, 頭部顔面外 稘々耳鼻咽喉科・シンポジウム)，金原出版（東 京) 1963 .

11) Antia, N. H. : Methods of Plastic Surgery in Leprosy, Lepr. India, $36: 269-81,1964$.

12）成田稳：らいに抒ける顔面形成外科，レプラ, $35: 247-61,1966$.

13）成田稔：ニッケルクロム合金の金属網利用し た隆鼻用プロテーゼについて，らい形成外科， $25: 6-10,1966$.

14）成田稔：造鼻用プロテーゼ，とくにその形態に つマて，らい形成外科，7:10-15，1967.

15）成田稔：全造舅術の問題点，らい形成外，30： 1-7, 1968.

16）鬼塚卓弥：造鼻術の反省，形成外科，14：465 74,1971 .

17）谷太三郎：造鼻術の反省, 形找外科, $14: 489-$ 94, 1971. 


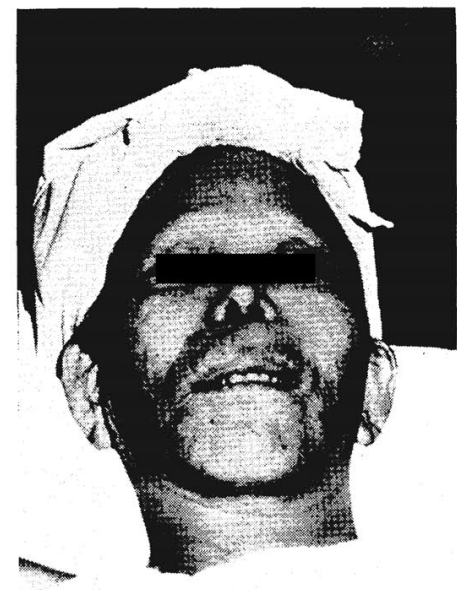

Fig. 1: Before the Operation

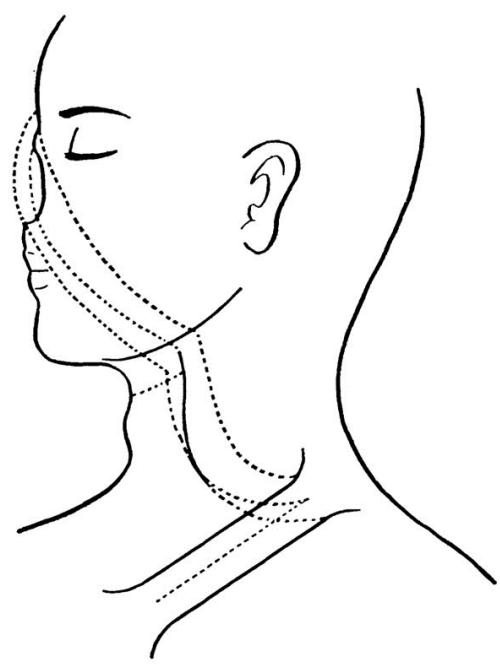

Schema 1: Transferring steps of the flap
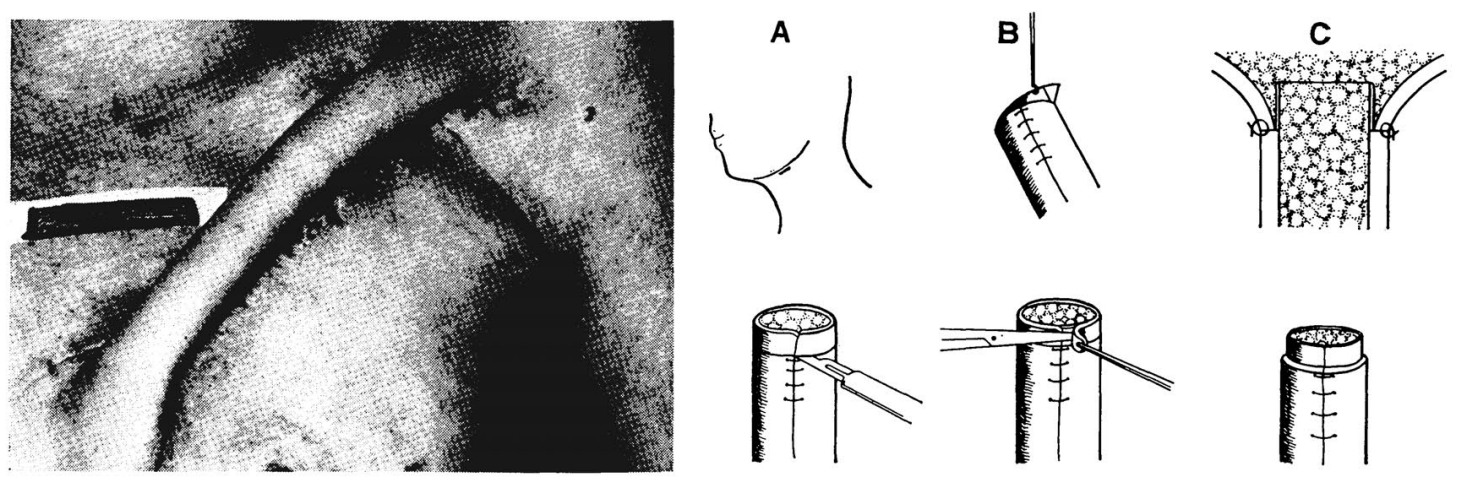

Fig. 2 : Acromiopectoral tubed pedicle flap building Schema $2:$ Insertion of the flap at the transferrence

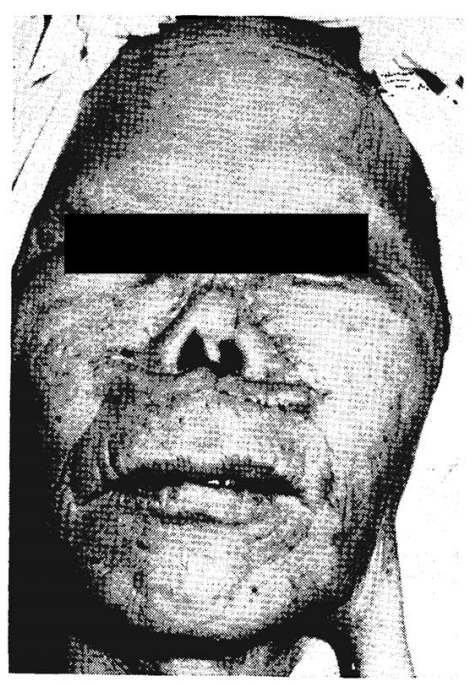

Fig. 3 : Corrected dish face
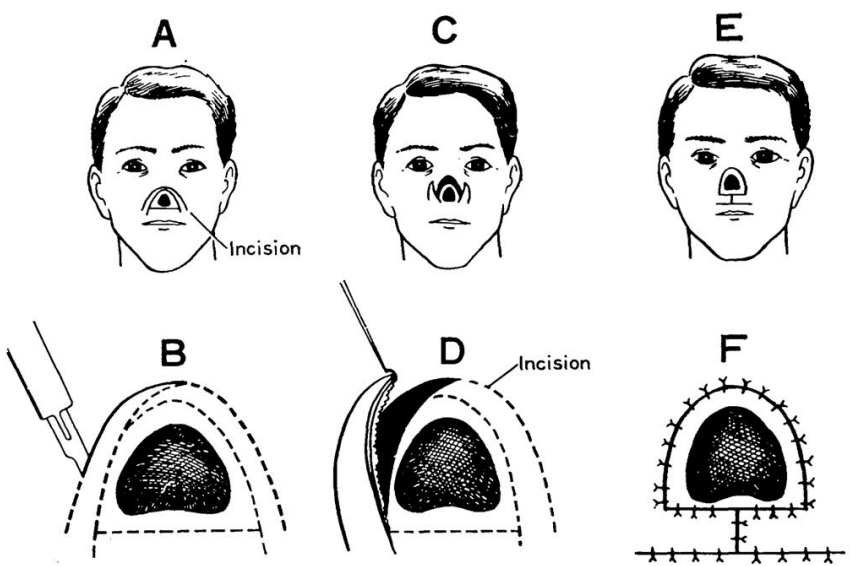

Schema 3 : Dish face correction procedure 


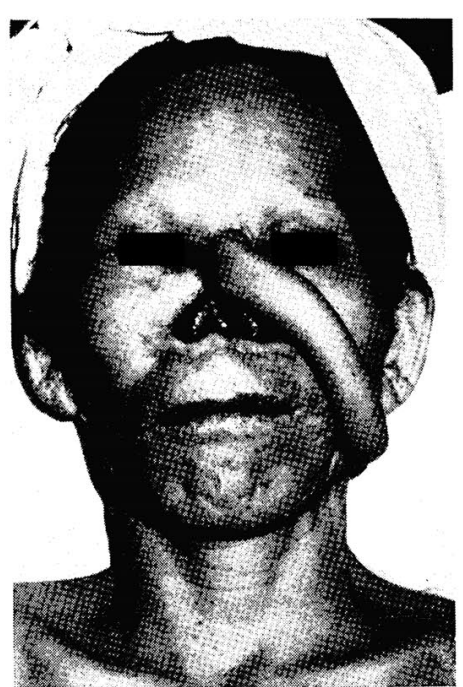

Fig. 4 : Migrated flap at nose

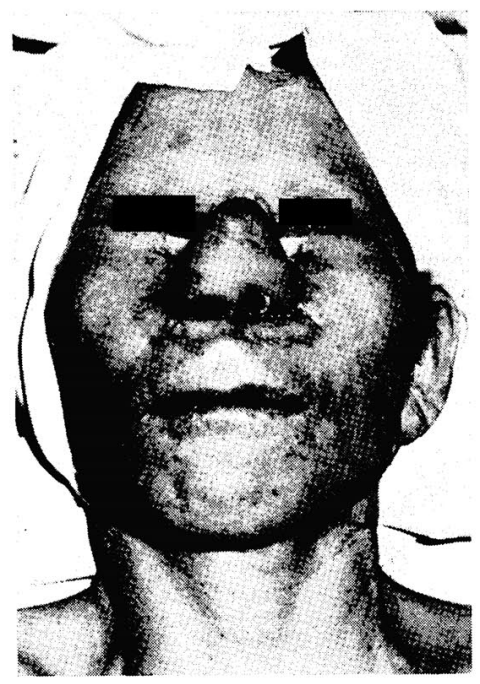

Fig. 5 : Plasted collumera and nose

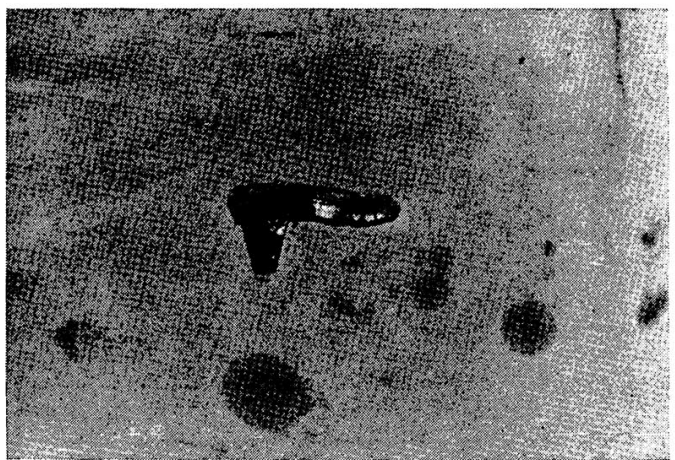

Fig. 6 : L-shaped prosthesis made from autogenous costal cartilage

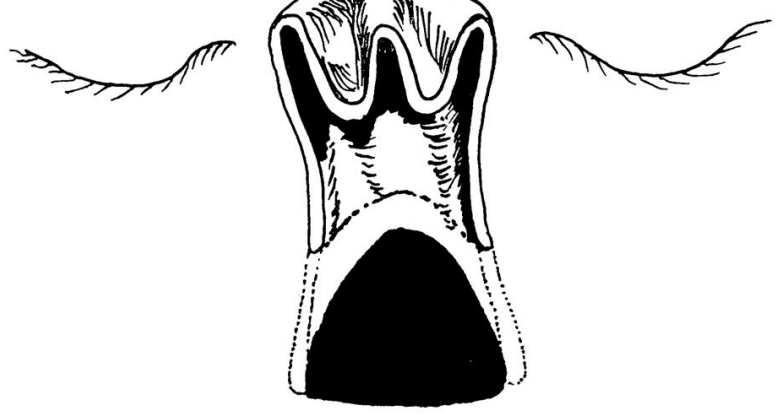

Schema 4 : Design of the flap

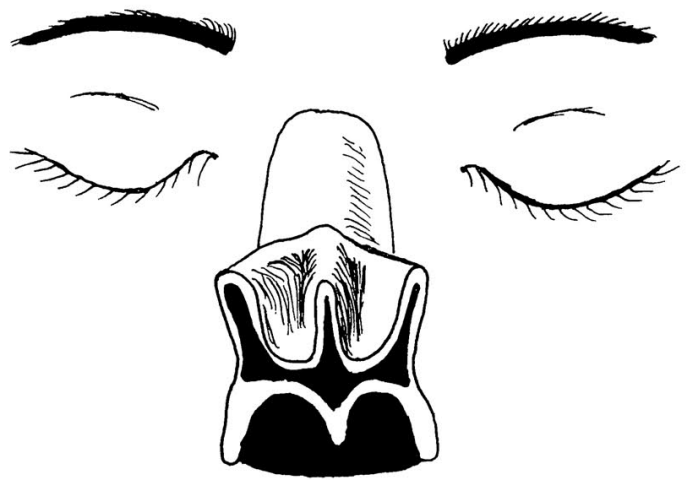

Schema 5: Migration of the designed flap at nasal region

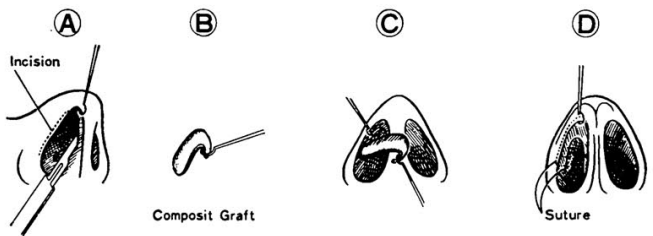

Schema 6 : Alar prosthesis (from herix) insertion 


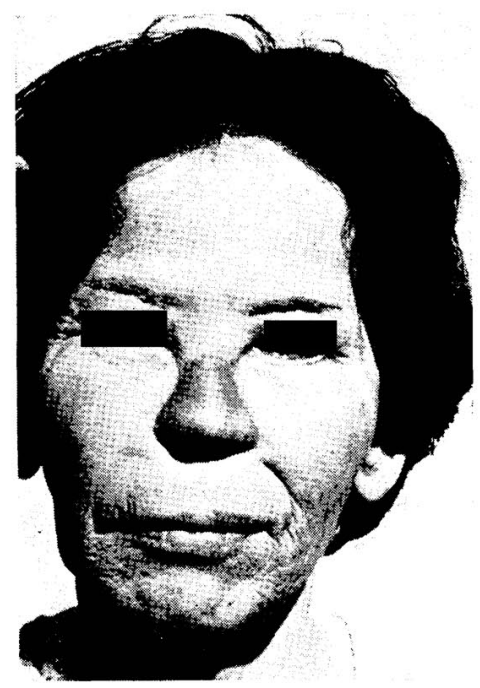

Fig. 7 : After final dressing

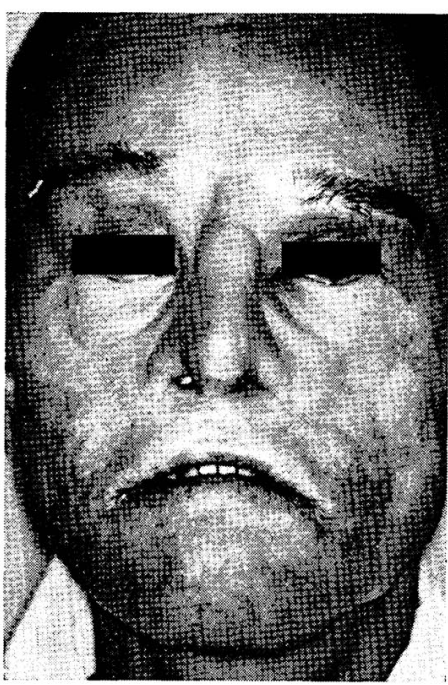

Fig. 8 : Spreaded teleangiectastia on plasted nose 